\title{
Spatial Form of Greenery in Strategic Environmental Management in the Context of Urban Adaptation to Climate Change
}

\author{
Elżbieta Szopińska ${ }^{1}$, Jan Kazak²*, Olgierd Kempa², Justyna Rubaszek ${ }^{1}$ \\ ${ }^{1}$ Wrocław University of Environmental and Life Sciences, Institute of Landscape Architecture, Wrocław, Poland \\ ${ }^{2}$ Wrocław University of Environmental and Life Sciences, Department of Spatial Economy, Wrocław, Poland
}

Received: 12 February 2018

Accepted: 13 June 2018

\begin{abstract}
Our article focuses on the problem of greenery management in urban areas in terms of the spatial form of greenery as well as biologically active areas. Due to the importance of the spatial form of greenery in shaping the positive features of the city's local climate, the authors have proposed a method for assessing the spatial form of greenery (MASFoG), which is an extension of the existing and widely used method. In addition to the inventory of plants, the spatial model has been created (the 3D model rendered in the geographic information system, GIS), which is a novelty for the method. The method allows for visualizing and calculating the spatial form of greenery - the real biologically active size of the studied area, as well as to estimate real losses in the environment resulting from the introduction of planned changes, e.g., cutting down greenery because of construction of new facilities. The method may facilitate management of the city's greenery, especially in planning and spatial development: (1) at the stage of drawing up the planning documents and (2) at the stage of specific investments before taking the final decision concerning their location and activities related to natural compensation.
\end{abstract}

Keywords: spatial form of greenery, biologically active area, urban adaptation, climate change, environmental management

\section{Introduction}

Implementing the concept of sustainable development is closely related to the systemic and strategic approach toward environmental resources management at the local level. Its essence can be summarized by the maxim

*e-mail: jan.kazak@upwr.edu.pl promoting the concept of sustainable development: "think globally, act locally" [1].

Effective environmental resource management of a given area requires proper expertise of the matter to be subject to the management process. It is also important to define the strategic development directions in a given area as well as goals to be achieved as a result of actions undertaken (planning, investment). Effective assessment should also involve assessment of the effects of implemented changes [2-4]. Such organization of 
the management process should apply to many aspects of the spatial development of contemporary cities. One of them is the environmental aspect, closely related to the adaptation process of cities to the changing climate conditions [5-7].

The increase in the Earth's average annual temperature has been confirmed by further reports of the Intergovernmental Panel on Climate Change (IPCC). The latest report - the Fifth Assessment Report (AR5), states that: "Each of the last three decades has been successively warmer on the Earth's surface than any preceding decade since 1850" and "the globally average combined land and ocean surface temperature data, as calculated by the linear trend, show warming of $0.85^{\circ} \mathrm{C}$ over the period of 1880 to 2012 " [8]. Notably, due to climate change, an increase in the intensity and frequency of extreme weather phenomena such as heavy rainfall, floods, heat waves and droughts has been observed. The $90 \%$ of climate change is caused by diverse human activities and resulting from them emissions of greenhouse gases such as carbon dioxide $\left(\mathrm{CO}_{2}\right)$, nitrogen dioxide $\left(\mathrm{NO}_{2}\right)$, methane $\left(\mathrm{CH}_{4}\right)$, and less frequently occurring but still having a strong impact: hydrofluorocarbons (HFCs), perfluorocarbons (PFCs) and sulphur hexafluoride $\left(\mathrm{SF}_{6}\right)$, as well as by deforestation and progressive urbanization [8]. It is predicted that Europe will be the fastest heating continent [9-10]. Since the year 2000, several extreme heat waves have been recorded in Europe: 2014 and 2015 have been the warmest years since instrumental records began. The average annual temperature for the last decade (2006-2015) was around $1.5^{\circ} \mathrm{C}$ above the pre-industrial level, which makes it the warmest decade on record [10].

Moreover, it is considered that heat waves exacerbated by the Urban Heat Island effect (UHI) will be more acutely felt in urban areas [10-12]. UHI is a phenomenon characterized by the occurrence of higher air temperatures in the city compared to non-urban areas [13-14]. UHI is the subject of multifaceted research - both the methods of measurement as well as determining and mitigating factors are put to examination [15-16]. UHI is the subject of research in Poland as well [17-20]. It is believed that the UHI intensity is conditioned not only by solar radiation, sky conditions, the wind system and city structure, but also by a large area of soil sealing, the type of materials used and the anthropogenic heat source generated by industrial combustion, traffic, air-conditioners and other human activities [13, 21-22].

High temperatures cause a nuisance to urban dwellers [23]. The research carried out in the years 1990-2004 within the EuroHeat project in nine European cities (Athens, Barcelona, Budapest, London, Milan, Munich, Paris, Rome and Valencia) indicated that high temperatures are especially dangerous to elderly people as they contribute to an increase in mortality from $7.6 \%$ to $33.6 \%$, depending on the examined city
[24]. Heat waves also cause higher energy consumption [25-26] as well as an increase in air pollution [27].

The need for taking action in order to adapt to climate change is strongly emphasized at the international level. It also finds reflection in various documents, including the EU Strategy on adaptation to climate change [28]. The strategy constitutes the basis for the member states to take adaptive action at the domestic, regional and local levels. Polish cities are also facing the challenge of developing adaptation plans [2930]. Biologically active areas should play an important role in the process of adapting cities to climate change due to the many functions they perform, including the effect of temperature reduction [31-33]. As a result of shading and transpiration, solar radiation is either deflected or absorbed by leaves and it is transformed into latent heat converting water from liquid to gas, which in turn results in lower leaf temperature, lower ambient air temperature and higher humidity [34]. Trees are the plants that have very favorable effects on ambient temperature [35-37] as they provide shade for areas and objects located in their neighborhood and have a greater assimilation surface compared to other plants like grasses and shrubs, and they assist in wind-shielding. The scope of effects that the green complex (tree stand) has on ambient temperature depends on the size of the area /surface that it occupies [38], as well as on the type of greenery and its quantity in a given area [3941]. The effects of greenery on temperature reduction in parks occurs even in small green areas (such as pocket parks) and in their immediate vicinity as long as they are appropriately saturated with greenery (42\%) [42]. Trees also exhibit the temperature-reducing effects better than open water surface areas. Steeneweld et al. have demonstrated that the water body increases UHI by $95 \%$, especially during the night and late summer. This phenomenon is associated with heat accumulation in water [43].

Biologically active areas referred to as green infrastructure play an important role in this process [44-46]. It is not a new idea that it is essential to take into account environmental factors, including biologically active areas, in the planning process of spatial development of cities. This issue was already addressed in the early 1970s by the Roman Club in the report "Limits of Growth" published in 1972. On the $40^{\text {th }}$ anniversary of its publication, the issue raised in the report was confirmed [47]. Over the last 40 years there has occurred an intense development of sciences concerning the environment and its protection, and the findings of these sciences have been included in proenvironmental policies in many countries around the world, e.g., in the field of acquiring alternative energy sources [48-50], reducing harmful gas emissions [51-52], reducing consumption of natural resources [53-55], or expanding the area covered by greenery $[38,56]$.

The intensive urbanization process leads to a reduction or even disappearance of areas covered by greenery [57], which along with progressive global 


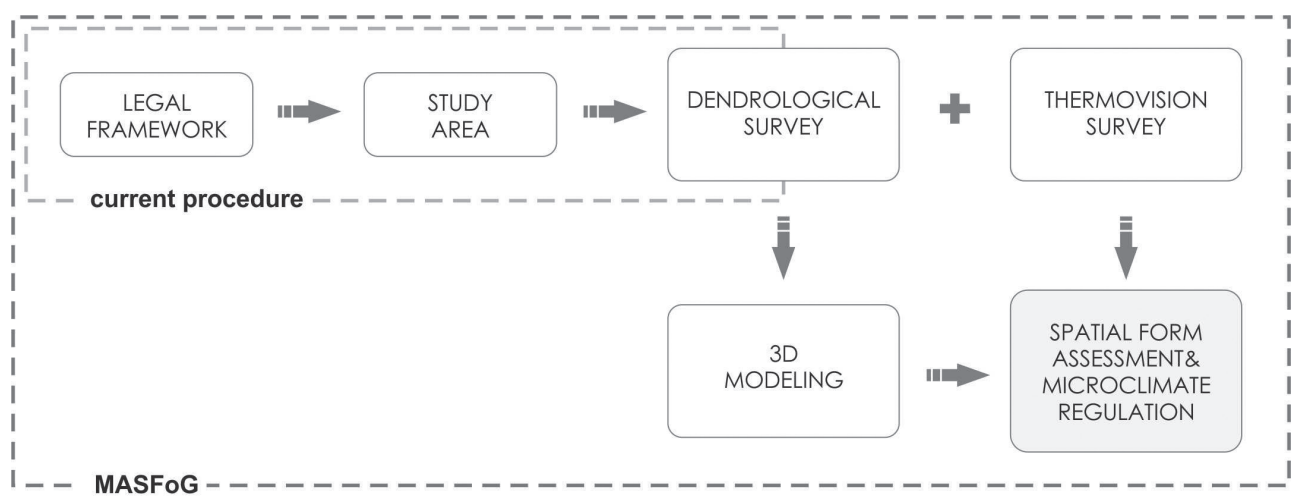

Fig. 1. MASFoG workflow.

warming is an unfavorable phenomenon resulting in deterioration of the quality of the environment and living conditions in urban areas [58]. The observed phenomena can be prevented, for instance by modifying the current approach toward the issues of shaping the urban space by means of greenery (vegetation), i.e., a biologically active area. Actions taken to adapt cities to climate change require the development of tools and methods supporting proper planning of the spatial structure of cities, including planning and management of green infrastructure. The use of such tools and methods will facilitate the right decisions regarding the use and purpose of areas. The undertaken research direction addresses one of the issues related to valorization of areas and assessing their suitability in terms of optimal spatial development in the future [59].

\section{Aims and Methods}

The aim of our article is to develop the method for assessing the spatial form of greenery (MASFoG) for strategic environmental management on an urban scale. The approach focus on spatial form of greenery as an important value in determining the biologically active area. The proposed method allows us to present forms of greenery with the use of 3D modelling created in the GIS environment. The method consisted of six stages, as shown in Fig. 1.

The first stage involved the analysis of the Polish legal provisions relating to biologically active areas. The regulations taken into account were the ones used in the planning, design-implementation and investment processes as follows: Regulation of the Minister of Infrastructure of 12 March 2009 amending the technical conditions that should be met by buildings and their location [60], Regulation of the Minister of Environment of 3 July 2017 on the rates of fees for removal of trees and shrubs [61] and the Nature Conservation Act of 16 April 2004 [62].

In the second stage of the research, based on the analysis of legislation, the test area was selected.
The verification method presented in this article comprised the area assigned for the planned investment of road construction on the Eastern Bridge (part of the Wrockaw ringroad). The surface of the test area comprised about 20 hectares.

The third stage involved a dendrological survey in the field study. In accordance with the current procedure, the dendrological survey includes updating the base map and inserting locations of trees in the form of a point on the map, assigning the inventory number, recognizing the species, measuring the trunk circumference, and assessing the health condition for each tree. In the proposed method, the survey additionally involves measuring height and the tree crown diameter. The differences between the current procedure and the proposed method in the field of dendrological survey can also be seen in Fig. 2.

\begin{tabular}{|c|c|}
\hline Current procedure & MASFOG \\
\hline LEGAL FRAMEWORK & LEGAL FRAMEWORK \\
\hline DENDROLOGICAL SURVEY & DENDROIOGICAL SURVEY \\
\hline LOCATING THE TREE ON THE BASIC MAP & LOCATING THE TREE ON THE BASIC MAP \\
\hline GIVING THE INVENIORY NUMBER & GIVING THE INVENTORY NUMBER \\
\hline RECOGNITION OF THE SPECIES & RECOGNITION OF THE SPECIES \\
\hline $\begin{array}{l}\text { MEASUREMENT OF THE TRUNK } \\
\text { CIRCUMFERENCE }\end{array}$ & $\begin{array}{l}\text { MEASUREMENT OF THE TRUNK } \\
\text { CIRCUMFERENCE }\end{array}$ \\
\hline$x$ & CROWN DIAMETER MEASUREMENT \\
\hline$x$ & HEIGHT MEASUREMENT \\
\hline ASSESSMENT OF THE HEALTH CONDITION & ASSESSMENT OF THE HEALTH CONDITION \\
\hline $\mathbf{x}$ & 3D MODELING \\
\hline $\mathbf{x}$ & THERMOVISION SURVEY \\
\hline $\mathrm{x}$ & $\begin{array}{c}\text { SPATIAL FORM } \\
\& \\
\text { MICROCUMATE REGULATION }\end{array}$ \\
\hline
\end{tabular}

Fig. 2. Comparison of the current procedure and the MASFoG. 
The thermovision survey constituted an additional element of the field study (4 test stages). The measurements conducted in the previously selected area allowed us to assess the effects of tree shading on different materials. Calculating the difference between the temperature of the sunny and shaded surfaces allowed us to assess the effects of high greenery on temperature reduction in the urban area. For the purpose of that study we used a FLIR i7 thermovision camera. The measurements were conducted on 6 different surfaces.

In the fifth stage, the field survey data (stage 3) were used to develop the 3D models of greenery. The model presents a set of solids, with individual parameters matching the elements of greenery in the test area. As a result of the visualization, it is possible to assess the current state of natural resources and their relationship with other elements of the city structure. The 3D model also allows us to enter information about the elements, which are to be removed, and thus to visualize potential environmental and spatial losses.

The final stage of the method involved assessing the parameters of spatial objects (greenery) in the city structure based on the 3D modeling. The acquired indicators show the potential for shading of the surface and, combined with the results obtained from the thermovision survey, they allow us to assess the potential for temperature reduction in the city. The acquired parameters describing biologically active areas (crowns of trees and their side walls) allow us to manage the environmental resources of the city, reaching beyond the existing standards of legal regulations.

\section{Results and Discussion}

The first step of the research was Polish legislation analysis in the context of urban greenery management on a city scale. The Regulation of the Minister of Infrastructure of March 12, 2009 on the technical conditions [60] that should be fulfilled by buildings and their location ( $\$ 3$ item 22 ) defines a biologically active area as an "area with soil surface managed in such a way that ensures natural vegetation, and also $50 \%$, but not less than $10 \mathrm{~m}^{2}$, of the surface of terraces and flat roofs with this type of surface, as well as surface water in this area." Next, the same document reads as follows: "In the building plots designated for development (...), at least $25 \%$ of the plot area should be arranged as a biologically active area, unless arrangements adopted under the local spatial development plan provide a different percentage" (Chapter 8, § 39). The cited definition of biologically active area does not distinguish the spatial form of greenery in such an area; it only states that the area is to "ensure natural vegetation," without specifying any kind of plants and their forms. For years municipal investments have been implemented in accordance with the applicable definition cited above, therefore many projects and solutions include mainly low greenery (herbaceous plants, shrubs) and extensively limit the presence of high greenery (trees). The restrictions on the use of trees have several reasons: the necessity to take into account higher financial means for implementing high greenery projects, the need for a larger area (i.e., at the stage of drawing up local development plans), and in the case of terraces and flat roofs for applying a thicker layer of soil and proper, often expensive, construction solutions that ensue from it.

In the face of current intensive development of urban areas, density of housing developments and simultaneous occurrence of adverse weather phenomena (the urban heat island), reduction of the percentage of land covered by trees is an extremely unfavorable phenomenon indicating that the concept of sustainable development is not properly implemented when it comes to improving a cities' local climate, present and forecasted, as well as adaptation of cities to climate change.

In view of the above findings, it is necessary to demand that all guidelines regarding the share of biologically active areas in municipal investments be included in planning documents drawn up at the local level, such as: the Study of Conditions and Directions of Spatial Development and the Local Spatial Development Plan. The Study is an expression of the spatial development policy of the borough (Polish gmina), while the Local Plan is a legal act regulating the principles of actual spatial development in the borough. Due to the importance of the Study in the process of creating Local Spatial Development Plans, provisions defining the development of areas covered by greenery and recommended forms of spatial vegetation (spatial structure of greenery) should be stated already at the stage of drawing up the document. Information regarding the size of the area and the spatial form of greenery should take into account its importance for creating positive features of the microclimate as well as the local climate of the city.

In addition to the observed phenomenon of climate change, urban areas are struggling with various environmental problems. Research carried out across Europe has revealed that the most serious problems of this kind include heavy atmospheric precipitation resulting in flooding, increased air pollution in the winter and an increasing number of hot days [17-18, 20]. It has been proven that among various vegetation forms, trees are the most effective when it comes to limiting the overheating of urban space.

Temperature reduction is caused by two factors: direct shading by trees and evapotranspiration. The range of beneficial effects of trees on the environment depends on their species, size and spatial form, crown structure and age. As the published research results indicate [38], urban spaces with a large area of land covered by trees and water reservoirs are the coldest spaces in the city. Temperature differences between high greenery complexes (parks, forests) and builtup areas can be around $2-3^{\circ} \mathrm{C}$ during the summertime. The environmental impact of greenery complexes on 

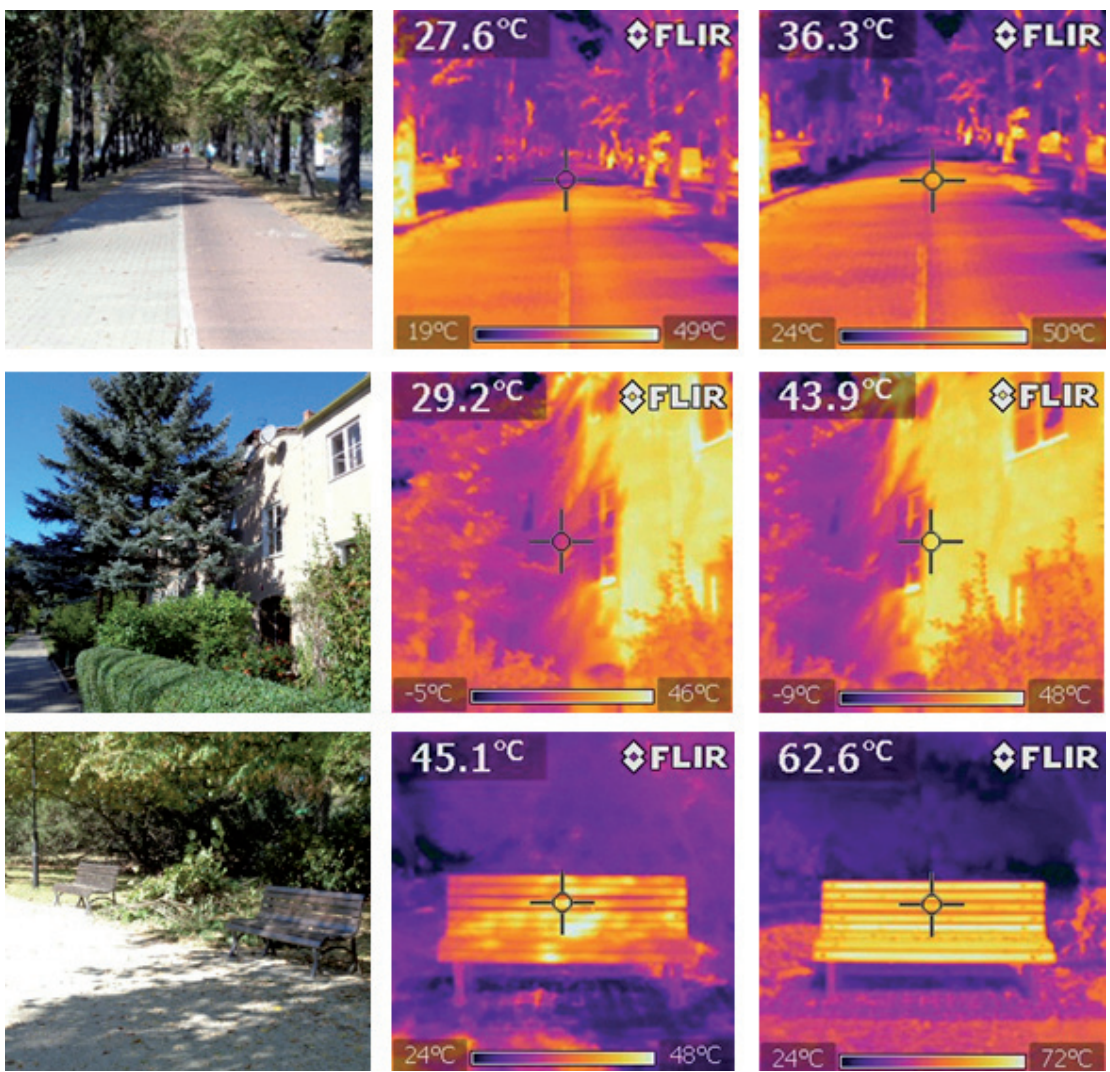

Fig. 3. The temperature measurement of shady and sunny surface of: concrete surface, plastered wall and painted wood.

the ambient temperature depends on the area of such complexes [38]. Therefore, it is important to create the largest network of connected sites covered by greenery in one system.

Although urban greenery fulfills many ecosystem services, in the context of this research only microclimate regulation in terms of temperature was analyzed. To illustrate the effect of greenery on the temperature of surfaces made of different materials, measurements were carried out by use of a thermal imaging camera FLIR i7. All thermal measurements were made on the same day between 13:00 and 14:00 $(\mathrm{UTC}+1)$ in order to illustrate the impact of the same conditions of solar radiation. In the city of Wrocław, six areas with a different spatial structure of greenery (low greenery - lawns and shrubs, high greenery trees) and various materials found in the environment (wood / wood covered with paint, concrete, asphalt, and mineral surfaces such as stone aggregate and plaster) were selected for the research (Fig. 3).

The conducted thermovision measurements have confirmed the hypothesis that trees have a more favorable effect on the ambient temperature than low greenery forms (shrubs, lawns). The temperature differences between the sunlit and shaded surfaces specified in Table 1 indicate that the difference also depends significantly on the material that covers or constitutes the surface. Thus, the indicated dependence

Table 1. Span between the temperatures of sunlit and shaded areas depending on the type of material of which the surfaces are made.

\begin{tabular}{|c|c|c|c|c|}
\hline $\begin{array}{c}\text { Number of } \\
\text { the examined surface }\end{array}$ & Type of material & $\begin{array}{c}\text { Temperature of the } \\
\text { shaded area }\left({ }^{\circ} \mathrm{C}\right)\end{array}$ & $\begin{array}{c}\text { Temperature of the sunlit } \\
\text { area }\left({ }^{\circ} \mathrm{C}\right)\end{array}$ & $\begin{array}{c}\text { Difference in temperatures } \\
\left({ }^{\circ} \mathrm{C}\right)\end{array}$ \\
\hline 1 & Grass & 26.6 & 32.7 & 6.1 \\
\hline $2^{*}$ & Concrete & 27.6 & 36.3 & 8.7 \\
\hline 3 & Mineral surface & 27.3 & 36.7 & 14.2 \\
\hline 4 & Asphalt & 25.0 & 39.2 & 14.7 \\
\hline $5^{*}$ & Plaster & 29.2 & 43.9 & 17.5 \\
\hline $6^{*}$ & Wood covered with paint & 45.1 & 62.6 & 9.4 \\
\hline
\end{tabular}

* photographs of the examined surfaces included in the article 


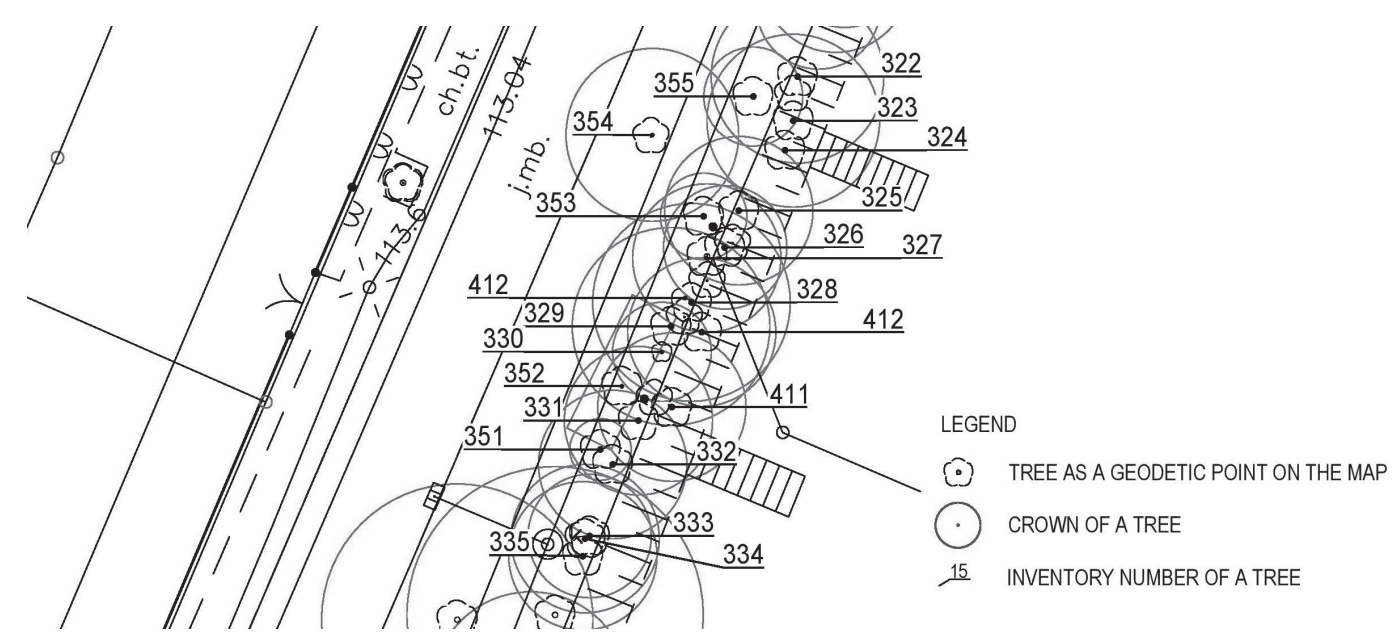

Fig. 4. The inventoried elements of greenery (trees) as part of the project documentation drawn up for the needs of the planned road investment.

can be used in practice for the selection of proper materials of urban surfaces [63].

As presented above, the thermoregulation function of urban greenery is strongly related with spatial forms of greenery. Therefore, effective strategic environmental management at the local scale should focus not only on numbers of planted or cut down pieces, but rather should include three dimensions. That is why in order to demonstrate the importance of the form of greenery in shaping the characteristics of local climate of the city (including the ambient temperature), this form should be the subject of detailed analyses in the city planning process and management of its environment. It is necessary to create tools facilitating the forecasting of effects that proposed spatial solutions (e.g. construction of roads, buildings, removal of trees) will have for the environment and microclimatic conditions of a given area. The method for assessing the spatial form of greenery (MASFoG) proposed by the authors using the $3 \mathrm{D}$ computer model created in the GIS environment can play an important role in this regard. In the model, greenery is shown spatially (in the shape of solids) and in relation to other elements of development (buildings, roads, etc.). It is therefore visualized as a real space of a biologically active area.

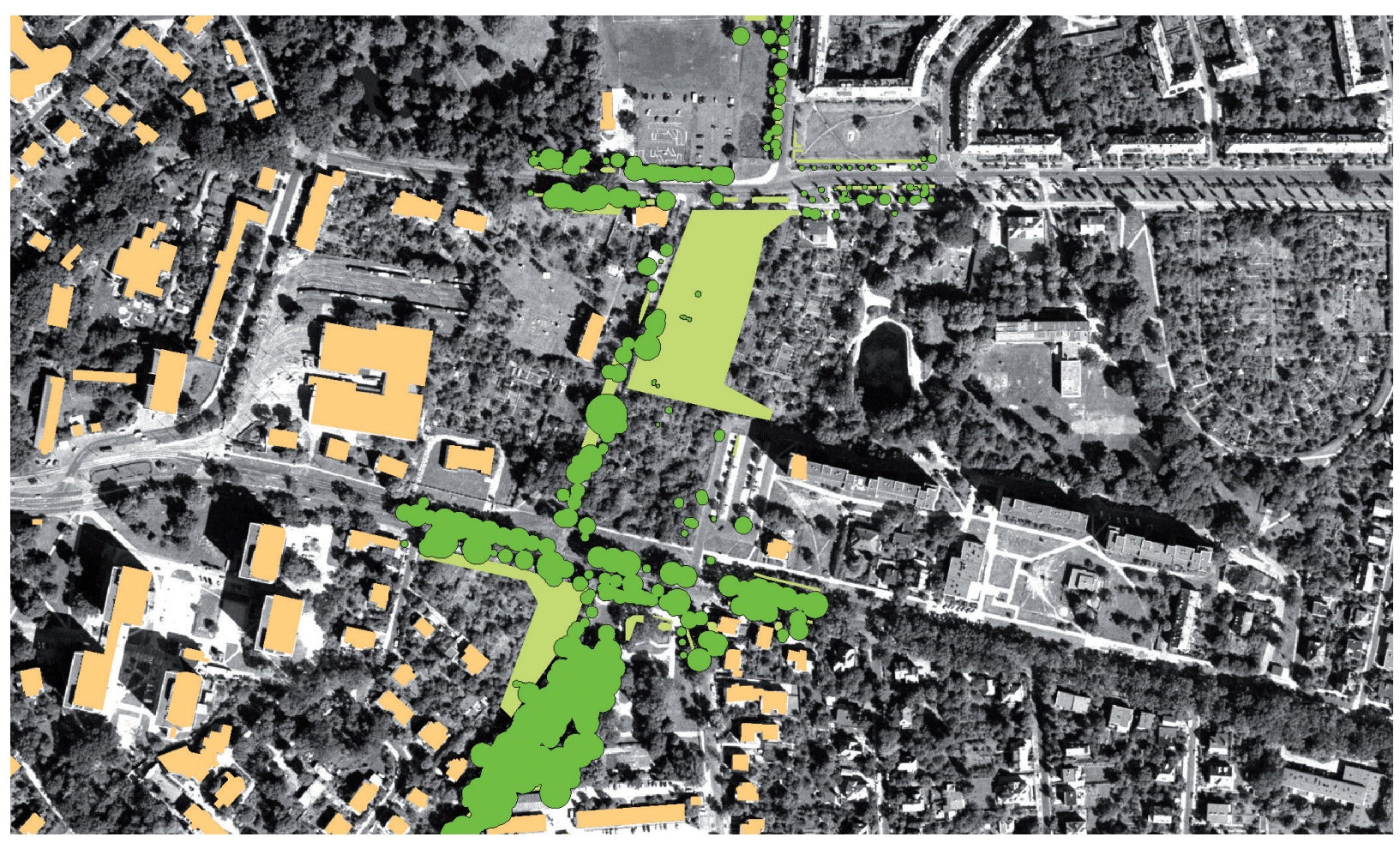

Fig. 5. The drawing in the GIS program presented the trees crowns projection. 


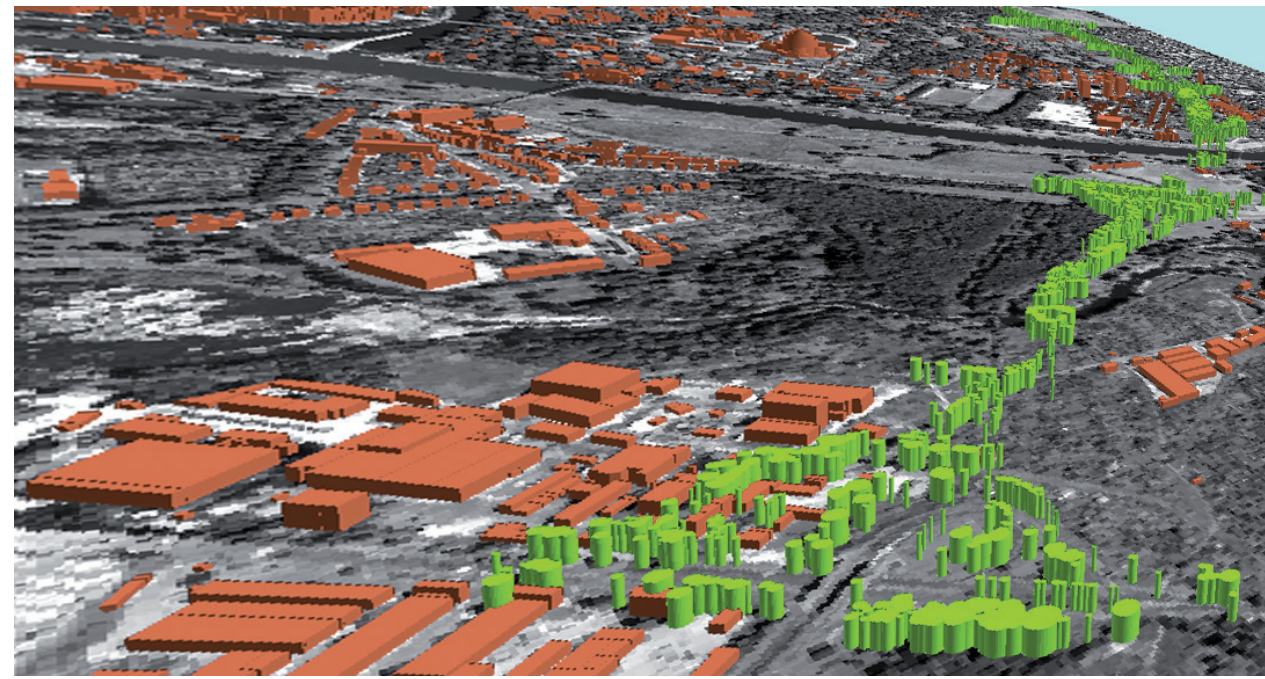

Fig. 6. The 3D model presenting the inventoried elements of greenery (trees) as solids.

The use of GIS tools in environmental research is becoming more and more popular [64-65], and - while used in conjunction with remote sensing - it is extremely effective for evaluating the spatial and temporal changes in urban land use and its cover [66]. However, these analyses do not take full advantage of the possibilities offered by 3D modelling. Our research checks the suitability of 3D applications for the management of urban space and greenery.

The presented method of assessing greenery with the use of the 3D model has been implemented in Wrocław at the site of the future construction of the Eastern Bridge together with new eastern bypasses of the city.

The study included 4,000 specimen of trees, for which, in the first stage of the work, a dendrological appraisal report was made (which is a basic and commonly used method of assessing greenery). In the report, each inventoried unit of greenery was given an inventory number and all the units were classified into taxonomic groups as well as certain data that was collected concerning tree parameters (trunk circumference at a height of $130 \mathrm{~cm}$, crown diameter, height) and health conditions. The collected data is presented both in a descriptive and graphical manner on the base map (Fig. 4). Detailed dendrometric data was used to develop drawings in the GIS environment by presenting the drawing with tree crown projection area (Fig. 5), the spatial model of trees in the context of other land development elements (Fig. 6) and the model of trees which are to be cut down because of the planned investment (Fig. 7, where the trees are highlighted in red). The order and type of works performed, the way it was made and the final result are summarized in Table 2. It was shown that with the number of inventoried trees of 4,000 pieces, the crown projection area is $119,227.8 \mathrm{~m}^{2}$, the projection area of the crowns

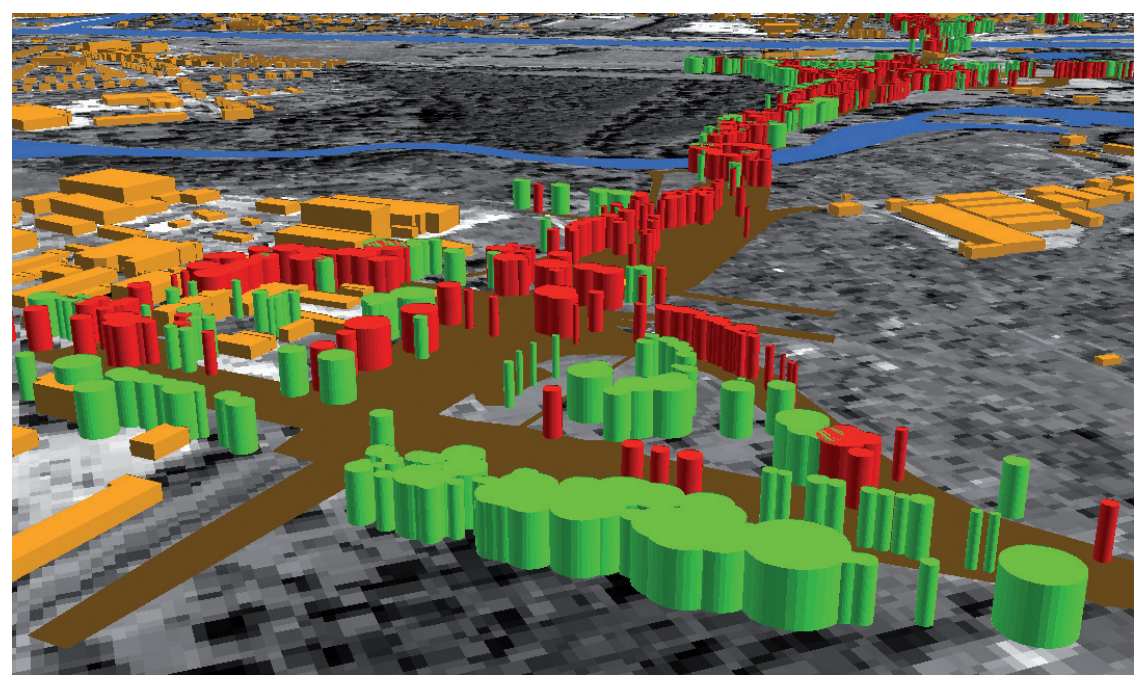

Fig. 7 The 3D model presenting the inventoried elements of greenery (trees) as solids - divided into trees that will remain (green) and those which will be cut down (red). 
Table 2. Method for assessing the spatial form of greenery by use of the 3D model created in the GIS environment - stages.

\begin{tabular}{|c|c|c|c|}
\hline Stage & Name of the stage & Manner / used tools & Result \\
\hline 1 & $\begin{array}{l}\text { Dendrological } \\
\text { appraisal report }\end{array}$ & $\begin{array}{l}\text { Field study - species identification } \\
\text { and field measurements, } \\
\text { placing information on the map (CAD) } \\
\text { and the data table (EXEL) }\end{array}$ & $\begin{array}{l}\text { Data in the table: } \\
\text { - number of pieces } \\
\text { - species (taxon) } \\
\text { - size of the unit (height, crown diameter, trunk circum- } \\
\text { ference) } \\
\text { - sanitary condition } \\
\text { Drawing on the map: } \\
\text { - trees as points with numbers (Fig. 2) }\end{array}$ \\
\hline 2 & $\begin{array}{l}\text { Introduction } \\
\text { of data into the GIS } \\
\text { program }\end{array}$ & $\begin{array}{c}\text { Introduction of data into the GIS program } \\
\text { (elements of greenery, existing objects and } \\
\text { the planned investment) }\end{array}$ & $\begin{array}{l}\text { Database in GIS } \\
\text { Base map with points and numbers in GIS as the basis } \\
\text { for generating the 3D model }\end{array}$ \\
\hline 3 & $\begin{array}{l}\text { Modelling in } \\
\text { the GIS program }\end{array}$ & $\begin{array}{c}\text { Generating the model } \\
\text { - showing the status prior to the invest- } \\
\text { ment }\end{array}$ & $\begin{array}{l}\text { Model showing the status of existing greenery in the } \\
\text { context of other forms of spatial development prior to } \\
\text { the planned investment. Drawing of the trees crown } \\
\text { projection (Fig. 3), 3D model (Fig. 4) }\end{array}$ \\
\hline 4 & $\begin{array}{l}\text { Modelling in } \\
\text { the GIS program }\end{array}$ & $\begin{array}{c}\text { Generating the model } \\
\text { - showing the status after the investment }\end{array}$ & $\begin{array}{l}\text { Model showing real losses in the environment and } \\
\text { changes in space resulting from the planned investment } \\
\text { (Fig. 5) }\end{array}$ \\
\hline
\end{tabular}

plus the side surface of the crown walls $470873.5 \mathrm{~m}^{2}$ and the volume occupied by tree crowns $1311505,8 \mathrm{~m}^{3}$ (Table 3).

Data of this type when enriched by another parameter that is leaf area density (LAD) (given for a particular species of plant) can also be used to calculate the tree assimilation area [67] or else the green plot ratio (GPR), a numerical indicator that reflects the degree of vegetation diversity in a given area; it is the highest in areas covered by trees and multi-layered spatial forms of greenery and the lowest in areas covered with grass [68]. GPR is meant to be a counterpart of the building area ratio used in city planning.

The 3D model (being an important component of our method of greenery assessment) allows us to illustrate the real size of environmental, climatic and landscape losses that will result from cutting down trees. It is a tool thanks to which we can visualize changes in the structure of the city, e.g., in the area of interrupting the continuity of ventilation wedges, acoustic and viewing barriers [69]. The model can be expanded by other factors, e.g., the time factor, with which it is possible to put the planned greenery (trees) on the map along with data on the average height and span of crowns at a particular stage of development (growth). It is possible to simulate changes and various transformation scenarios in the selected area on the basis of the measurements of the current and future status. The main features of the green evaluation method with the spatial model are presented in graphical form (Fig. 8).
The 3D modeling proposed in MASFoG can also be carried out by use of the programme of Screening Tools of Estate Environment and Evaluation (STEVE). STEVE was developed on the basis of the GIS platform in order to facilitate the interlinking of climate research with spatial planning and design [70]. As a webbased application, it allows us to count the minimum, medium and maximum temperatures in a specific area and to simulate temperature changes after entering new elements or removing the existing ones. In the case of the application of this programme within MASFoG, the stage of the thermovision camera testing could be omitted, making the method more accessible to planners, designers and public administration bodies responsible for assessing and supervising the design and investment process. Furthermore, development of the stage of temperature measurement conducted at different times of the year, day and night could render a more complete picture of variations in surface temperatures of the studied area, as well as could be used for a thorough examination of the impact of a given green complex on the temperature of pavement and air, within the area and outside it.

Some cities all over the world have developed standards or indicators that function as local laws. The Green Development Standard for the city of Toronto states that $30 \%$ of the parking area and other paved surfaces should be shaded by trees [71]. The indicators such as the Biotope Area Factor (BAF) of Berlin, Green Space Factor (GSF) of Malmö [72] and Seattle Green

Table 3. Results of assessment of greenery carried out in the area of the planned road investment.

\begin{tabular}{|c|c|c|c|}
\hline $\begin{array}{c}\text { Number of inventoried } \\
\text { trees (pcs.) }\end{array}$ & $\begin{array}{c}\text { Sum of the tree crown projection } \\
\left(\mathrm{m}^{2}\right)\end{array}$ & $\begin{array}{c}\text { Sum of the tree crown projection and } \\
\text { surface of the tree side wall }\left(\mathrm{m}^{2}\right)\end{array}$ & $\begin{array}{c}\text { The tree as a spatial form } \\
\left(\mathrm{m}^{3}\right)\end{array}$ \\
\hline 4000 pcs. & 119227,8 & 470873,5 & 1311505,8 \\
\hline
\end{tabular}




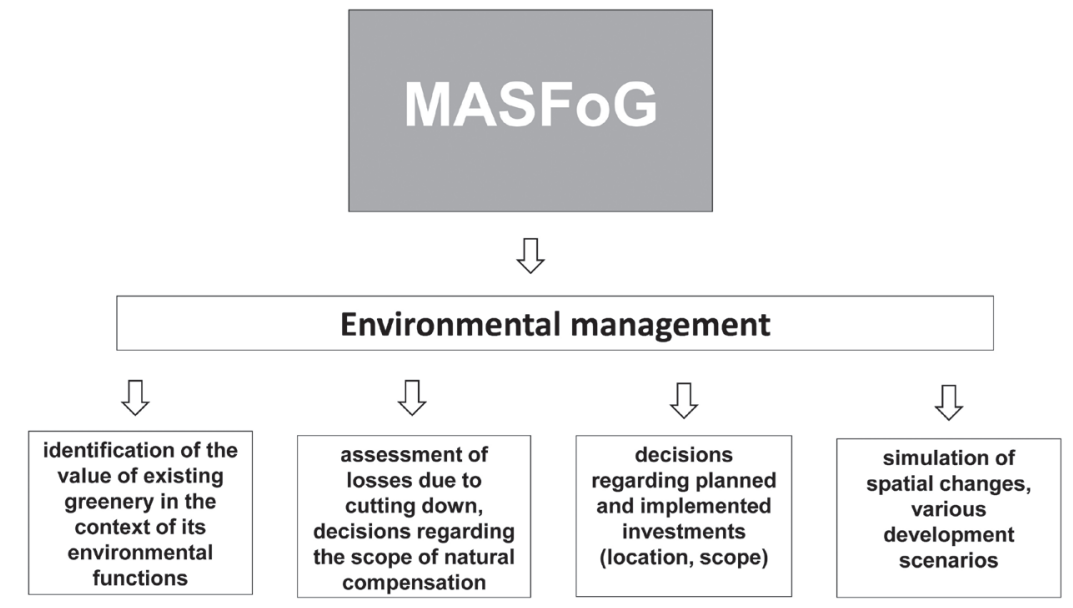

Fig. 8. The MASFoG applicability.

Factor [73] are mandatory in planning the green areas of these cities. They determine the ratio of the area covered with open water surfaces, permeable surfaces, devices for infiltration of storm water and, most importantly, greenery in relation to the total area surface. In view of GSF and SGF indicators, trees constitute a separate category subject to classification. The BAF indicator is the basis of Berlin's landscape plans, GSF is used for planning and development of new multi-family estates, and SGF is used for the area of the whole city. The indicators and standards guarantee the optimal development of individual areas with regard to green areas, and their functioning confirms the necessity for regulating the green issues and their precision in spatial planning and development.

It should be noted that in contemporary Poland, the assessment of greenery, as being prepared for investment needs, must fulfill clauses of Polish law, i.e., the Act of July 7, 1994 Construction Law [74], Act of 16 April 2004 on the protection of nature [62] and Regulation of the Minister of the Environment of 3 July 2017 on the amount of charges for removal of trees and shrubs [61]. In accordance with the above documents, losses in the environment, with a possible removal of trees, are presented as a number of cut-out pieces, and not as actually lost assimilation space.

In view of the above, the authors of the article recognise the enormous need to ensure precise records on biologically active areas, as well as forms of greenery occurring there, in planning documents such as: the Study of Conditions and Directions of Spatial Development and the Local Spatial Development Plan. Both documents are interrelated - the Study is a reflection of the municipality's spatial policy while the Local Plan is a legal act regulating the principles of the municipality's actual spatial development. Considering the importance of the Study in the process of creating Local Spatial Development Plans, already at the stage of preparing them, there should be included records on the recommended spatial forms of greenery within areas of individual functions. Indispensably, examinations of the existing studies should be carried out in respect of their regulations of the green forms and structures, which would allow us to identify the most common deficiencies and facilitate more appropriate planning and development of the environment in the future.

As a result of our inquiry we advocate for a wider formula of assessment that takes into account the spatial form of greenery, we believe it would be helpful in making decisions concerning the functions of areas and various types of investments, especially strategic ones, which strongly violate the natural structure of the city and thus prepare the city for climate change.

\section{Conclusions}

The suggested method for assessing the spatial form of greenery (MASFoG) goes beyond the accepted and binding standards and, in the authors' opinion, may be a tool supporting environmental management (in particular the city's greenery). It seems fully justified in the context of the United Nations Framework Convention on Climate Change and helps in the effective implementation of the international objectives and their implementation at the local level. The results obtained from assessing greenery by use of the 3D model allow us to: (1) better recognize the value of existing greenery in the context of its various environmental functions, (2) assess losses due to cutting down and decisions regarding the scope of natural compensation, (3) decisions regarding planned and implemented investments (location, scope) and (4) simulation of spatial changes that draw up various development scenarios.

\section{Acknowledgements}

Special thanks are due to Mariusz Szymanowski for his help in preparing the $3 \mathrm{D}$ model. 


\section{Conflict of Interest}

The authors declare no conflict of interest

\section{References}

1. STONE D. Think global, act local or think local, act global? Knowledge production in the global agora. Central European University Conference "Reshaping globalization: multilateral dialogues and new policy initiatives". Budapest, Hungary, 2001.

2. KAZAK J., SZEWRAŃSKI S. Indicator-based environmental assessment of spatial planning with the use of CommunityVis. Geoinformatics for City Transformations. GIS Ostrava 2013. 10 ${ }^{\text {th }}$ International Symposium. 168, Ostrava, Czech Republic, 2013.

3. PRZYBYŁA K., KULCZYK-DYNOWSKA A., KACHNIARZ M. Quality of life in the regional capitals of Poland. Journal of Economic Issues. 48 (1), 181, 2014.

4. ŚWIĄDER M., SZEWRAŃSKI S., KAZAK J. SpatialTemporal Diversification of Poverty in Wroclaw, World Multidisciplinary Civil Engineering-Architecture-Urban Planning Symposium 2016. Procedia Engineering. 161, 1596, 2016.

5. CARTER J.G., CAVAN G., CONNELLY A., GUY S., HANDLEY J., KAZMIERCZAK A. Climate change and the city: Building capacity for urban adaptation. Progress in Planning. 95, 1, 2015.

6. TOKARCZYK-DOROCIAK K., WALTER E., KOBIERSKA K., KOŁODYNSKI R. Rainwater management in the urban landscape of Wroclaw in terms of adaptation to climate changes, Journal of Ecological Engineering. 18 (6), 171, 2017.

7. CLOUTIER G., PAPIN M., BIZIER CH. Do-it-yourself (DIY) adaptation: Civic initiatives as drivers to address climate change at the urban scale. Cities. 74, 284, 2018. Available online 4 January 2018, ISSN 0264-2751, https:// doi.org/10.1016/j.cities.2017.12.018.

8. IPCC. Climate Change 2014: Synthesis Report. Contribution of Working Groups I, II and III to the Fifth Assessment Report of the Intergovernmental Panel on Climate Change [Core Writing Team, R.K. Pachauri and L.A. Meyer (eds.)]. Geneva, 2014.

9. JACOB D., PETERSEN J., EGGERT B. EUROCORDEX: new high-resolution climate change projections for European impact research. Reg Environ Change. 14, 563, 2014.

10. EEA. Climate change, impacts and vulnerabilities in Europe 2016. An indicator-based report. Publication Office of the European Union, Luxemburg, 2017.

11. United Nations Human Settlements Programme (UNHabitat). Cities and Climate Change: Global Report on Human Settlements. Earthscan, London; Washington, 2011.

12. ROSENZWEIG C., SOLECKI W.D., HAMMER S.A., MEHROTRA S. (Eds.). Climate Change and Cities: First Assessment Report of the Urban Climate Change Research Network. University Press, Cambridge, 2011.

13. OKE T.R. Boundary layer climate $\left(2^{\text {nd }}\right.$ ed.). Methuen, London, 1987.

14. RIZWAN A.M., DENNIS L.Y.C., LIU C. A review on the generation, determination and mitigation of Urban Heat Island. Journal of Environmental Sciences. 20, 120, 2008.
15. DEILAMI K., KAMRUZZAMAN M., LIU Y. Urban heat island effect: A systematic review of spatiotemporal factors, data, methods, and mitigation measures. International Journal of Applied Earth Observation and Geoinformation. 67, 30, 2018.

16. COSEO P., LARSEN L. How factors of land use/land cover, building configuration, and adjacent heat sources and sinks explain Urban Heat Islands in Chicago, Landscape and Urban Planning. 125, 117, 2014.

17. FORTUNIAK K. Miejska wyspa ciepła. Podstawy energetyczne, studia eksperymentalne, modele numeryczne i statystyczne. Wydawnictwo Uniwersytetu Łódzkiego, Łódź, 2003.

18. SZYMANOWSKI M. Miejska wyspa ciepła we Wrocławiu. Wydawnictwo Uniwersytetu Wrocławskiego, Wrocław, 2004

19. KOŻUCHOWSKI K. Klimat Polski. Nowe spojrzenie. Wydawnictwo Naukowe PWN, Warszawa, 2011.

20. KAZAK J.K. The use of a decision support system for sustainable urbanization and thermal comfort in adaptation to climate change actions - the case of the Wrockaw larger urban zone (Poland). Sustainability. 10, 1083, 2018.

21. SANTAMOURIS M. (ed.). Energy and climate in the urban built environment. James \& James, London, 2001.

22. WONG N. H., CHEN Y. Tropical urban head islands climate buildings and greenery. Taylor \& Francis, London; New York, 2009.

23. HAINES A., KOVATS R.S., CAMPBELL-LENDRUM D., CORVALAN C. Climate change and human health: Impacts, vulnerability and public health. Public Health. 120, 585, 2006

24. D'IPPOLITI D., MICHELOZZI P., MARINO C., DE'DONATO F., MENNE B., KATSOUYANNI K., KIRCHMAYER U., ANALITIS A., MEDINA-RAMÓN M., PALDY A., ATKINSON R., KOVATS S., BISANTI L., SCHNEIDER A., LEFRANC A., IÑIGUEZ C., PERUCCI C.A. The impact of heat waves on mortality in 9 European cities: results from the EuroHEAT project. Environmental Health. 9, 37, 2010.

25. RADHI H., SHARPLE S., ASSEM E. Impact of urban heat islands on the thermal comfort and cooling energy demand of artificial islands - A case study of AMWAJ Islands in Bahrain. Sustainable Cities and Society. 19, 310, 2015.

26. SANTAMOURIS M., CARTALIS C., SYNNEFA A., KOLOKOTSA D. On the impact of urban heat island and global warming on the power demand and electricity consumption of buildings - A review. Energy and Buildings. 98, 119, 2015.

27. EEA. Air quality in Europe. Report 4/2012. Office for Official Publications of the European Union, Luxembourg, 2012.

28. EU. The EU Strategy on adaptation to climate change, 2013.

29. MINISTERSTWO ŚRODOWISKA. Strategiczny plan adaptacji dla sektorów i obszarów wrażliwych na zmiany klimatu do roku $2020 \mathrm{z}$ perspektywą do roku 2030. Warszawa, 2013.

30. KIEŁKOWSKA J., TOKARCZYK-DOROCIAK K., KAZAK J., SZEWRAŃSKI S., VAN HOOF J. Urban Adaptation to Climate Change Plans and Policies - the Conceptual Framework of a Methodological Approach. Journal of Ecological Engineering. 19 (2), 50, 2018.

31. BOWLER D., BUYUNG-ALI L., KNIGHT T. M., PULLIN A.S. Urban greening to cool towns and cities: A 
systematic review of the empirical evidence. Landscape and Urban Planning. 97, 147, 2010.

32. ZHAO C., FU G., LIU X., FU F. Urban planning indicators, morphology and climate indicators: A case study for a north-south transect of Beijing, China. Building and Environment. 46, 1174, 2011.

33. WANG Y., BERARDI U., AKBARI H., Comparing the effects of urban heat island mitigation strategies for Toronto, Canada. Energy Build. 114, 2, 2016.

34. WONG N.H., JUSUF S.K. Urban heat island and mitigation strategies at city and building level. Kolokotosa D.D., Santamouris M., Akbari H. (Eds.). Advances in the development of cool materials for the built environment. Bentham Science Publishers, 2013.

35. AKBARI H., POMERANTZ M., TAHA H. Cool surfaces and shade trees to reduce energy use and improve air quality in urban areas. Solar Energ y. 70, 295, 2001.

36. AKBARI H., KONOPACKY S., Energy effects of heat island reduction strategies in Toronto, Canada. Energy. 29, 191, 2004.

37. COSEO P., LARSEN L. Cooling the Heat Island in Compact Urban Environments: The Effectiveness of Chicago's Green Alley Program. Procedia Engineering. 118, 691, 2015.

38. KONIJNENDIJK C.C., NILSSON K., RANDRUP T.B., SCHPPERIJN J. Urban Forests and Trees. Springer, Berlin Heidelberg, 2005.

39. POTCHTER O., COHEN P., BITAN A. Climatic behavior of various urban parks during hot and humid summer in the Mediterranean city of Tel Aviv, Israel. International Journal of Climatology. 26, 1695, 2006.

40. RAHMAN M.A., ARMSON D., ENNOS A.R. A comparison of the growth and cooling effectiveness of five commonly planted urban tree species. Urban Ecosystems. 18, 371, 2015.

41. LEHMANN I., MATHEY J., RÖßLER S., BRÄUER A., GOLDBERG V. Urban vegetation structure types as a methodological approach for identifying ecosystem services - Application to the analysis of micro-climatic effects. Ecological Indicators. 42, 58, 2014.

42. LIN P., SIU YU LAU S., QIN H., GOU Z. Effects of urban planning indicators on urban heat island: a case study of pocket parks in high-rise high-density environment. Landscape and Urban Planning. 168, 48, 2017.

43. STEENEVELD G.J., KOOPMANS S., HEUSINKVELD B.G., THEEUWES N.E. Refreshing the role of open water surfaces on mitigating the maximum urban heat island effect. Landscape and Urban Planning. 121, 92, 2014.

44. DEMUZERE M., ORRU K., HEIDRICH O., OLAZABAL E., GENELETTI D., ORRU H., BHAVE A.G., MITTAL N., FELIU E., FAEHNLE M. Mitigating and adapting to climate change: Multifunctional and multi scale assessment of green urban infrastructure. Journal of Environmental Management. 146, 107, 2014.

45. NORTON B.A., COUTTS A.M., LIVESLEY S.J., HARRIS R.J., HUNTER A.M., WILLIAMS N.S.G. Planning for cooler cities: A framework to prioritize green infrastructure to mitigate high temperatures in urban landscapes. Landscape and Urban Planning. 134, 127, 2015.

46. SUSSAMS L., W. SHEATE W.R. EALES R.P. Green infrastructure as a climate change adaptation policy intervention: Mudding the waters or clearing a path to a more secure future? Journal of Environmental Management, 147 (1), 184, 2015.
47. RANDERS J., 2052: A Global Forecast for the Next Forty Years, Chelsea Green Publishing House, 2012.

48. BOERENFIJN P., KAZAK J.K., SCHELLEN L., VAN HOOF J. A multi-case study of innovations in energy performance of social housing for older adults in the Netherlands. Energy and Buildings. 158, 1762, 2018.

49. KAZAK J., VAN HOOF J., SZEWRAŃSKI S. Challenges in the wind turbines location process in Central Europe The use of spatial decision support systems. Renewable and Sustainable Energy Reviews. 76, 425, 2017.

50. WOCH F., HERNIK J., LINKE H.J., SANKOWSKI E., BĘCZKOWSKA M., NOSZCZYK T. Renewable Energy and Rural Autonomy: A Case Study with Generalizations. Pol. J. Environ. Stud. 26 (6), 2823, 2017.

51. TALBI B. $\mathrm{CO}_{2}$ emissions reduction in road transport sector in Tunisia, Renewable and Sustainable Energy Reviews. 69, 232, 2017.

52. SKIBA M., MRÓWCZYŃSKA M., BAZANKRZYWOSZAŃSKA A. Modeling the economic dependence between town development policy and increasing energy effectiveness with neural networks. Case study: The town of Zielona Góra. Applied Energy. 188, 356, 2017.

53. MIAO CH., FANG D., SUN L., LUO Q. Natural resources utilization efficiency under the influence of green technological innovation. Resources, Conservation and Recycling. 126, 153, 2017.

54. SZEWRAŃSKI S., KAZAK J., ŻMUDA R., WAWER R. Indicator-Based Assessment for Soil Resource Management in the Wrocław Larger Urban Zone of Poland. Pol. J. Environ. Stud. 26 (5) 2239, 2017.

55. DĄBROWSKA J., BAWIEC A., PAWĘSKA K., KAMIŃSKA J., STODOLAK R. Assessing the impact of wastewater effluent diversion on water quality. Pol. J. Environ. Stud. 26 (1), 9, 2017.

56. SZYMAŃSKA D., LEWANDOWSKA A., ROGATKA K. Temporal trend of green areas in Poland between 2004 and 2012. Urban Forestry \& Urban Greening. 14, 1009, 2015.

57. BYOMKESH T., NAKAGOSHI N., DEWAN A.M. Urbanization and green space dynamics in Greater Dhaka. Bangladesh. Landscape Ecol. Eng. 8, 45, 2012.

58. VAN HOOF J., SCHELLEN L., SOEBARTO V., WONG J.K.W., KAZAK J.K. Ten questions concerning thermal comfort and ageing. Building and Environment. 120, 123, 2017.

59. RAJAN N.M., JAYALAKSHMI S. Predictive species habitat distribution modelling of indian sandalwood tree using GIS. Pol. J. Environ. Stud. 26 (4), 1627, 2017.

60. The Regulation of the Minister of Infrastructure of March 12, 2009 on the technical conditions which should be fulfilled by buildings and their location, as amended Rozporządzenie Ministra Infrastruktury z dnia 12 marca 2009 r. w sprawie warunków technicznych, jakim powinny odpowiadać budynki i ich usytuowanie, z późniejszymi zmianami (Dz.U. 2013 poz. 926).

61. Regulation of the Minister of the Environment of 3 July 2017 on the amount of charges for removal of trees and shrubs - Rozporządzenie Ministra Środowiska z 3 lipca 2017 w sprawie wysokości stawek opłat za usunięcie drzew i krzewów (Dz. U. 2017 poz. 1330).

62. Act of 16 April 2004 on the protection of nature, as amended - Ustawa z dnia 16 kwietnia 2004 r. o ochronie przyrody, z późniejszymi zmianami (Dz. U. 2004 nr 92 poz. 880).

63. GUO G., WU Z., XIAO R., CHEN Y., LIU X., ZHANG X. Impacts of urban biophysical composition on land surface 
temperature in urban heat island clusters. Landscape and Urban Planning, 135, 1, 2015.

64. TARIG A.A., MARUF M., SERTER A. GIS-based study on the susceptibility of Dubai creek (UAE) to eutrophication. Pol. J. Environ. Stud. 25 (6), 2275, 2016.

65. WANG S.H., SHANG M., ZHOU Y., LIU W.L., WANG F., WANG L.T., Resources and environmental carrying capacity using RS and GIS, Pol. J. Environ. Stud. 26 (6), 2793, 2017.

66. DEWAN A.M., YAMAGUCHI Y. Land use and land cover change in Greater Dhaka, Bangladesh: Using remote sensing to promote sustainable urbanization. Applied Geography. 29, 390, 2009.

67. PEPER P.J., MC PHERSON E.G. Evaluation of four methods for estimating leaf area of isolated trees, Urban Forestry and Urban Greening 2, 2, 2003.

68. ONG B.L. Green plot ratio: an ecological measure for architecture and urban planning, Landscape and Urban Planning, 63, 197, 2003.

69. SZOPINSKA E. Struktura przestrzenna zieleni jako element kształtowania klimatu miasta. Problemy planistyczne - wiosna 2011. Zachodnia Okręgowa Izba Urbanistów z siedzibą we Wrocławiu. 105, Wrocław, 2011.

70. WONG N.H., JUSUF S.K., TAN C.L. Integrated urban microclimate assessment method as a sustainable urban development and urban design tool. Landscape and Urban Planning. 10, 386, 2011.

71. WANG Y, BERARDI U., AKBARI H. Comparing the effects of urban heat island mitigation strategies for Toronto, Canada. Energy and Buildings. 114, 2, 2016.

72. HAGEN K., STILES R. Contribution of landscape design to changing urban climate conditions. Müller N., Werner P., Kelcev J.G. (Eds.). Urban Biodiversity and Design. Wiley-Blackwell, Oxford, 2010.

73. HIRST J., MORLEY J., BANG K. Functional Landscapes: Assessing elements of Seattle Green Factor. International Report. The Berger Partnership PS, 2008.

74. Act of July 7, 1994 - Construction Law - Ustawa z dnia 7 lipca 1994 r., as amended - Prawo budowlane, z późniejszymi zmianami (Dz. U. 2010 nr 121 poz. 809). 